\title{
Differential expression of antioxidant genes during clinical mastitis of cow caused by Staphylococcus aureus and Escherichia coli
}

\author{
Reza Asadpour $^{1 *}$, Pedram Zangiband ${ }^{1}$, Katayoon Nofouzi ${ }^{2}$, and Adel Saberivand ${ }^{1}$ \\ ${ }^{1}$ Department of Clinical Science, Faculty of Veterinary Medicine, University of Tabriz, Tabriz, Iran \\ ${ }^{2}$ Department of Pathobiology, Faculty of Veterinary Medicine, University of Tabriz, Iran, Tabriz, Iran
}

\begin{abstract}
ASADPOUR, R., P. ZANGIBAND, K. NOFOUZI, A. SABERIVAND: Differential expression of antioxidant genes during clinical mastitis of cow caused by Staphylococcus aureus and Escherichia coli. Vet. arhiv 91, 451458, 2021.
\end{abstract}

\section{ABSTRACT}

There is considerable interest in the hypothesis that oxidative stress is enhanced in the pathophysiology of clinical mastitis. The main goal of this research was to establish profiles of antioxidant gene expression in the milk of cows with clinical mastitis. Standard bacteriology was conducted on pretreatment milk specimens from 77 cows with clinical mastitis between 15 and 70 days in milk (DIM). Examinations were performed on mRNA expression of antioxidant genes, such as catalase (CAT), glutathione peroxidase (GPx), and superoxide dismutase (SOD). Additionally, levels of lipid peroxidation were measured in milk samples from healthy cows and those with clinical mastitis. The isolated bacteria consisted of Staphylococcus aureus (S. aureus, 10.48\%), Streptococcus agalactiae (7.69\%), Streptococcus dysagalactiae (6.29\%), and Escherichia coli (E. coli, 29.37\%). E. coli was the most prevalent pathogen found in the milk of cows with clinical mastitis in early lactation. The mean level of malondialdehyde (MDA) in clinical mastitis samples was significantly higher $(\mathrm{P}<0.05)$ than that of healthy cows. The results revealed that the expression profiles of SOD in mastitis milk induced by $S$. aureus were significantly $(\mathrm{P}<0.0001)$ up-regulated compared with E.coli. In addition, the mRNA levels of GPx in mastitis milk due to E.coli were significantly $(\mathrm{P}<0.0001)$ over expressed compared to $S$. aureus. CAT gene expression had a tendency to be enhanced in mastitis milk induced by $S$. aureus compared with mastitis in cows due to E.coli. These results showed that the mRNA levels of antioxidant genes may differ depending on the type of bacteria, and diminished expression of antioxidant genes might increase susceptibility to mastitis.

Key words: gene expression; Staphylococcus aureus; Escherichia coli; mastitis; dairy cows

\section{Introduction}

Mastitis is the most common disease of dairy cows and has known harmful effects on animal welfare and the profitability of dairy farms (RUEGG 2017). Early lactation occurs due to alterations in nutrient delivery patterns to regulate metabolism and maintain immune function, with wide-ranging changes in both the immune system and blood parameters (ZARRIN et al., 2017; WANKHADE et al., 2017). There is evidence that immunosuppression may affect the udder system at this time (ALERI et al., 2019). Immunosuppression and inflammation were reported to be caused by altered metabolites and hormonal systems, inflammation, and hepatic impairment due to negative energy balance in early

\footnotetext{
*Corresponding author:

Reza Asadpour, Department of Clinical Science, Faculty of Veterinary Medicine, University of Tabriz, Tabriz, Iran, Phone: +98 914419 2377; E-mail: r_asadpour@tabrizu.ac.ir
} 
lactation (AITKEN et al., 2009). Changes in blood parameters and hormones during parturition lead to an increase in reactive oxygen species (ROS).

Oxidative stress enhances the release of cytokines in the acute phase, which may also increase tissue damage during severe inflammatory reactions (CUSCIERI and MAIER, 2007). According to previous studies, the bacterial activity of neutrophils under inflammatory situations is controlled by ROS (RINADLI et al., 2007). Furthermore, the extra quantity of ROS in the absence of an optimal total antioxidant leads to the predominance of ROS, and compromises the immune system of cows (SORDILLO and AITKEN, 2009). In previous years, a wide range of immunological profiles and their related responses were established for Gram-positive and Germ-negative mammary gland infections (DENIS et al., 2006; PETZL et al., 2018). A study revealed that both clinical mastitis and sub-clinical mastitis contribute to the release of free radicals, increased overall oxidant activity, and decreased antioxidant capacity in milk (SHARMA et al., 2011). However, there are no available data on the antioxidant gene expression profile in clinical mastitis during early lactation. The goal of this research was, therefore, to examine alterations in the expression of mRNA antioxidant genes in milk samples of cows with mastitis caused by $S$. aureus and E. coli

\section{Materials and methods}

Animals and collection of samples. Seventyseven samples of milk were collected from cows with clinical mastitis and healthy animals between DIM 15 and DIM 70 during regular visits to dairy farms. Milk samples from all four quarters for each animal were pooled and subjected to the California mastitis test (CMT) and somatic cell count (SCC) in two groups of cows. Group I (Healthy cows, $\mathrm{n}=20$ ) consisted of control cattle with less than 200,000 cells/ml of SCC, with negative CMT, and no clinical symptoms of mastitis. Group II (clinical mastitis by $E$. coli, $\mathrm{n}=42$ and by $S$. aureus, $\mathrm{n}=15$ ) comprised cows with clinical mastitis, who were considered to have clinical symptoms of mastitis, including changes in the appearance of milk and different stages of udder inflammatory response (HOVINEN et al., 2008).

Bacteriology. A procedure previously described was applied for bacteriological examination of milk samples (MARKEY et al., 2013). Milk samples were sent quickly (1-2 h) and aseptically to the laboratory in a cool box for further examination. Milk samples with positive reaction to the CMT test were inoculated separately on MacConkey agar and blood agar by the streak-plating method. Plates were then kept in aerobic conditions at $37^{\circ} \mathrm{C}$ for $24 \mathrm{~h}$. Following incubation, bacterial colonies were assessed on the basis of morphology, color change, and hemolytic appearance. A pure bacterial culture was produced by sub-culture from the main cultures. Gram staining and conventional biochemical assessment were characteristic of each isolated and purified colony.

Isolation and identification of E. coli. Five pink colored colonies from MacConkey agar were randomly chosen and relocated to a single plate of triple sugar iron (TSI) agar and eosin methylen-blue lactose sucrose (EMB) agar, and then incubated under aerobic conditions at $37{ }^{\circ} \mathrm{C}$ for $24 \mathrm{~h}$. Following incubation, under the same conditions, the presumed isolate of the bacteria was distinguished by conventional Gram staining and biochemical tests (QUINN et al., 2011).

Confinement and identification of $S$. aureus. From each blood agar cultured sample, a loop-full of bacteria colony was streaked onto mannitol salt agar (MSA) and then incubated aerobically at $37^{\circ} \mathrm{C}$ for $24 \mathrm{~h}$. Colonies with yellow color were mannitolpositive and suspected as $S$. aureus. Each presumed segregate of the bacteria was distinguished by Gram staining and traditional biochemical tests, such as catalase and tube coagulase assays for $S$. aureus (QUINN et al., 2011).

Measurement of milk MDA levels. The thiobarbituric acid reaction was conducted using the modified method of WONG et al. (1987). Following initial centrifugation of normal and mastitis milk samples, the supernatant was added to the tube at $10,000 \mathrm{~g}$ for 20 minutes. Some $0.6 \%$ thiobarbituric acid (TBA) was then added, mixed, and incubated in a water bath for 45 minutes. MDA reacted with TBA in the presence of $0.2 \%$ of 
2,6-bis(1,1-dimetyoetylo)-4-metylofenol (BHT). Following centrifugation at $2000 \mathrm{~g}$ for 10 minutes, the supernatant was transferred to the microplate. This process is based on the response of a free MDA with TBA for the generation of an MDA-TBA additive. The MDA-TBA additive can be easily measured spectrophotometrically $(\mathrm{OD}=532 \mathrm{~nm})$.

Preparation of milk samples for RT-PCR. This approach was updated according to an earlier study (POKORSKA et al., 2016). Briefly, nearly $10 \mathrm{~mL}$ of normal and mastitis milk (S.aureus and E. coli) were transferred to sterile tubes and centrifuged at $7000 \mathrm{~g}$ at $4{ }^{\circ} \mathrm{C}$ for 10 minutes. The milk fat topmost supernatant was then extracted from the top of the somatic cells, and the milk protein and the remaining supernatant were transferred to $2 \mathrm{~mL}$ of sterile protein. The mixture was centrifuged at $5000 \mathrm{~g}$ for 3 minutes $\left(4^{\circ} \mathrm{C}\right)$, followed by removing the supernatant. The pellet was rinsed with a 1 $\mathrm{mL}$ buffer of $2.5 \mathrm{mM}$ EDTA and $15 \mathrm{mM}$ Tris-Hcl.
This combination was centrifuged at $5000 \mathrm{~g}$ at $4{ }^{\circ} \mathrm{C}$ for 3 minutes. The supernatant was eliminated, and this step was repeated to achieve a clear supernatant.

Real-time PCR. Levels of gene transcript were assessed by real-time quantitative PCR. Briefly, total RNA was extracted from the milk somatic cell pellet (Yekta Tajhiz Azema, Iran), according to the manufacturer's protocols. Its yield and purity were assessed at 260 and $280 \mathrm{~nm}$, respectively, using a Nano drop ND-2000 spectrophotometer. An amount of 2- $\mu$ g total RNA was used for complementary DNA (cDNA) synthesis using a two step RT-PCR Kit according to the manufacture's protocol. Then $2 \mu \mathrm{L}$ of cDNA were transferred to a tube, adding Taq polymerase, Master Mix (Takara, Japan) and $2 \mu \mathrm{L}$ of specific primer for the PCR mix. The RTPCR reaction was performed according to the instructions of the Master SYBR Green Kit (Takara, Japan) guides. The primer sequences for the genes analyzed are reported in Table 1.

Table 1. Primer sequences used for real-time PCR amplifications of selected genes in milk samples

\begin{tabular}{|l|l|c|c|c|c|}
\hline $\begin{array}{l}\text { Genes } \\
\text { Primer })\end{array}$ & Primer sequences (5-3) & $\begin{array}{c}\text { GeneBank } \\
\text { accession no }\end{array}$ & Product size & $\begin{array}{c}\text { Primer } \\
\text { (nm) }\end{array}$ & $\begin{array}{c}\text { Amplification } \\
\text { efficiency }(\%)\end{array}$ \\
\hline GPx(f) & GCAAGGTGCTGCTCATTGAG & NM_174076 & 82 & 150 & 109.67 \\
\hline GPx $^{\circledR}$ & CGCTGCAGGTCATTCATCTG & & & 300 & \\
\hline SOD(F) & TGTTGCCATCGTGGATATTGTAG & NM_174615 & 102 & 150 & 98.93 \\
\hline SOD & CCCAAGTCATCTGGTTTTTCATG & & & 150 & \\
\hline GAPDH(F) & TGACCCCTTCATTGACCTTCA & BTU85042 & 66 & 300 & 97.83 \\
\hline GAPDH(R) & AACTTGCCGTGGGTGGAAT & & & 150 & \\
\hline
\end{tabular}

F- forward; R - reverse; GPx - glutathione peroxidase; SOD - superoxide dismutase, GAPDH - glyceraldehyde-3-phosphate dehydrogenase

Real time PCR thermal conditions were 35 cycles $\left(94{ }^{\circ} \mathrm{C}, 30\right.$ seconds at $56^{\circ} \mathrm{C}, 45$ seconds at $72{ }^{\circ} \mathrm{C}, 40$ seconds), and the final step was adjusted by the DNA thermal cycler at $72{ }^{\circ} \mathrm{C}$ for 1 minute. The fluorescence density was registered at the end of each process. Specimens were assessed in duplicate mean values for quantification. The relative expression values of the target genes had normalized normalized GAPD) as the internal reference gene, and $2^{-\Delta \Delta \mathrm{Ct}}$ formula was applied for relative quantification.
Statistical analysis. Statistical analysis was performed using the SPSS version 21.0 package (SPSS Inc., Chicago, IL, USA). Data obtained from our study were expressed as mean \pm SEM per group and the statistically significances were evaluated by one-way ANOVA, and followed by Turkey's posthoc test. Values were considered to be statistically significant when $\mathrm{P}<0.05$. 


\section{Results}

Bacterial isolates. Standard bacteriology has been conducted for pre-treatment of milk specimens of dairy cattle with clinical mastitis, as shown in (Table 2).

Table 2. Distribution of bacterial isolates form milk samples collected from dairy cattle from clinical mastitis in early lactation

\begin{tabular}{|l|c|c|}
\hline Bacteria identified & No. & Prevalence (\%) \\
\hline Streptococcus spp. & 30 & 20.97 \\
\hline Streptococcus agalactiae & 11 & 7.69 \\
\hline Streptococcus dysgalactiae & 9 & 6.29 \\
\hline Staphylococcus aureus & 15 & 10.48 \\
\hline Coagulase negative & 24 & 16.78 \\
\hline Escherichia coli & 42 & 29.37 \\
\hline Gram-negative bacilli & 3 & 2.09 \\
\hline Mixed infection & 4 & 2.79 \\
\hline Contamination & 5 & 3.49 \\
\hline
\end{tabular}

The isolated bacteria from clinical mastitis in dairy cattle were $S$. aureus (10.48\%), Streptococcus agalactiae (7.69\%), Streptococcus dysagalactiae (6.29\%), other Streptococcus spp. (20.97\%), and E. coli (29.37.\%). In addition, Coagulase negative Staphylococci have been isolated from $24(16.78 \%)$ of the milk samples. E.coli and Streptococcus have been the predominant isolates accounting for $29.37 \%(n=42)$ and $20.97 \%(n=30)$ of isolates, respectively. In addition, of the identified different pathogens, only a small percentage of quarters was reported with mixed infections. Five samples were reported as being infected in the laboratory. As shown in (Table 2), E. coli was the most common pathogen found in cows milk clinical mastitis according to the results of standard laboratory culture.

Determination MDA Levels. The mean MDA level in clinical mastitis milk (38.55 \pm $1.96 \mathrm{nmol} / \mathrm{mL}$ ) was significantly higher than that in normal milk $(19.5 \pm 2.91 \mathrm{nmol} / \mathrm{mL})$.

Gene expression. The results revealed that the mRNA levels of SOD gene expression in the milk mastitis cows induced by E.coli and $S$. aureus were significantly decreased $(\mathrm{P}<0.0001)$ compared to control group. The expression profiles of SOD in milk mastitis induced by $S$. aureus were significantly $(\mathrm{P}<0.0001)$ up regulated compared with E. coli (Fig. 1.).

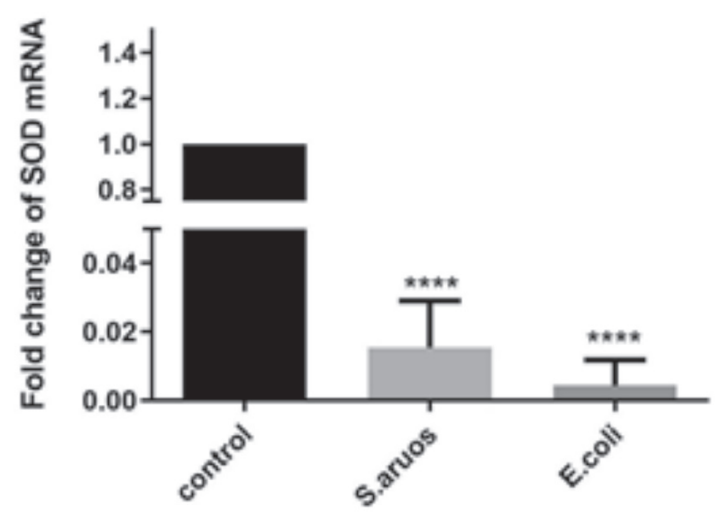

Fig. 1. Expression levels of superoxide dismutase (SOD) gene expression in cows with $E$. coli, and $S$. aureus mastitis compared with control group.* Each bar represents the average fold change over basal promoter activity. $* \mathrm{P}<0.05, * * * \mathrm{P}<0.001$, and $* * * * \mathrm{P}<0.0001$

The mRNA levels of GPx in the milk mastitis cows induced by $S$. aureus and E.coli had significantly $(\mathrm{P}<0.0001)$ down regulated compared with healthy cows. In addition, the mRNA levels of GPx in milk mastitis duo to E.coli were significantly $(\mathrm{P}<0.0001)$ over expressed compared with $S$. aureus (Fig. 2.).

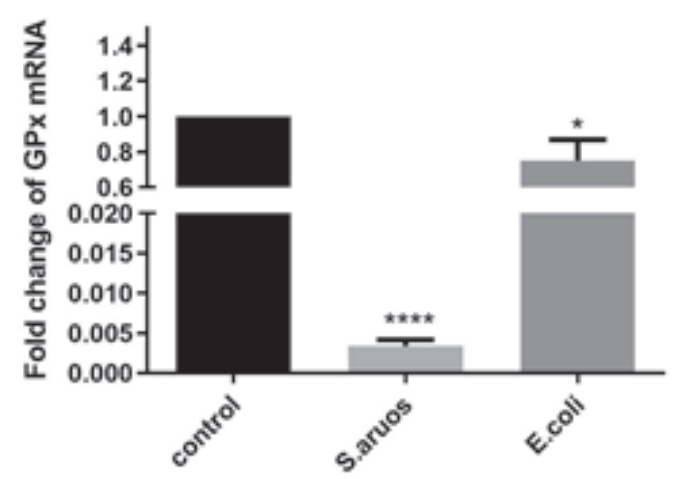

Fig. 2. Expression levels of Glutathione peroxidase (GPx) gene expression in cows with E. coli, and $S$. aureus mastitis compared with control group.* Each bar represents the average fold change over basal promoter activity. ${ }^{*} \mathrm{P}<0.05, * * * \mathrm{P}<0.001$ and $* * * * \mathrm{P}<0.0001$

CAT gene expression in the milk mastitis cows, had tendency to enhance significantly $(\mathrm{P}<0.001)$ with $S$. aureus mastitis compared with mastitis cows with E.coli. However, the mRNA expression of the CAT reduced significantly in milk mastitis cows induced by E. coli mastitis compared to the control group $(\mathrm{P}<0.0001)$ (Fig. 3.). 


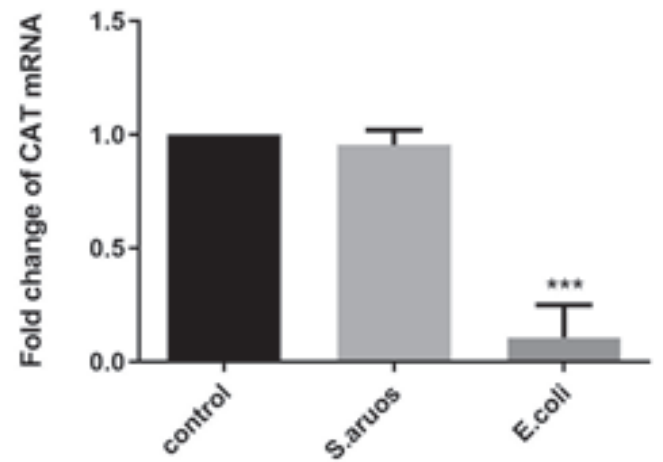

Fig. 3. Expression levels of catalase (CAT) gene expression in cows with E. coli, and S. aureus mastitis compared with control group. "Each bar represents the average fold change over basal promoter activity. $* \mathrm{P}<0.05, * * * \mathrm{P}<0.001$ and $* * * * \mathrm{P}<0.0001$

\section{Discussion}

Previous data suggest a possible association between reduced antioxidant capacity and increased pro-inflammatory status and this relationship could play an important role in the susceptibility of dairy cattle disease during the postpartum period (SORDILLO and AITKEN, 2009 ; ABUELO et al., 2015 ). Thus, recognition of antioxidant gene expression patterns may provide perspectives into the biological processes of their transmitted proteins and the protein interaction systems regulating cell reactions for extracellular stimulation. This study found a significant effect of infection on the amount of MDA in milk samples of experimental cows. The highest concentration of MDA was detected in cows with high somatic cell counts and those with clinical mastitis. Similarly, SHARMA et al. (2016), reported that dairy cows had low oxidative stress and low antioxidant protection during early lactation, which might be due to increased susceptibility to mastitis. Moreover, other findings from aforementioned study showed significant declines in CAT and SOD expression by $E$. coli, with a significant increase of mRNA levels GPx in $S$. aureus in comparison to control group. A previous research showed that SOD activity for natural milk decreased in the first and second months of lactation, then increased in the fifth and sixth months of lactation, and stabilized in the seventh and eighth lactation months (WANG et al., 2000). Our results indicated that the expression of SOD gene was significantly lower for both $S$. aureus and E. coli mastitis than the control cows. Our findings showed a significant increase in the mRNA levels of SOD in cows with $S$. aureus. These findings are inconsistent with research showing that, there is no association between SOD and mastitis caused by S. aureus (DAS and BISHAYI, 2009), while some reports suggested that SOD had only a minimal effect on virulence (SCHNEIDER et al., 2002). Furthermore, in a mouse abscess model resulting from $S$. aureus infection, recognized as the dominant SOD activity in S. aureus, had no affected on $S$. aureus virulence (CLEMENTS et al., 1999)

Oxidative factors decrease the enzyme activity and increase ROS levels, which cause the destruction of cellular structure and an increase in inflammation and, as a result, a decrease in antioxidant defense followed by a reduction in SOD enzyme levels (BIRBEN et al., 2012). In accordance with our research, VALCHEVA-TRAYKOVA et al. (2018) presented evidence that continuous or very high oxidative stress could deepen the protein damage and decrease SOD activity through direct oxidative damage to the SOD molecules, or through oxidative stress-altered gene expression, or both. In contrast with our results, it was shown that transcription and activity of SOD increased in the post-exponential growth phase during aerobic in vitro growth of $S$. aureus, and steadily increased during the stationary process (KARAVOLOS et al., 2003). Contradictions in the findings might be associated with lower intakes of most nutrients other than energy, hormonal, metabolic changes, mastitis type, and time of sampling.

Our study revealed decreased CAT mRNA levels due to E.coli intra mammary infection (IMI). This is consistent with what has been observed in previous research, which showed a decline in the mRNA expression levels of CAT in cattle with gangrenous mastitis (El-DEEB, 2013; IBRAHIM et al., 2016). However, a previous research referred to an increase in CAT due to $S$. aureus, even though the increase was reported to be of low significance (PETZL et al., 2018). Similarly, our research shows that acute clinical mastitis caused by $S$. aureus causes changes in blood hormones, such as glucose 
and insulin, resulting in an increase in the mRNA expression levels of CAT.

The finding of this study revealed that the mRNA levels of GPx increased in E.coli mastitis compared to $S$. aureus. It has been shown that lipopolysaccharides (LPSs) in the cell wall have receptor structures for host cells and, as soon as they are bonded to the polysaccharide receptor in the wall, the bacteria lead to a further increase in the GPx enzyme (RAY et al., 2013). Expression of GPx mRNA is particularly sensitive to any changes in ROS accumulation thus an increase in GPx mRNA is an excellent indicator of oxidative stress (LIMA et al., 2015). Overall, these findings are in accordance with findings reported by ARENAS et al. (2010) revealed that this enzyme has been shown to defend against the harmful effects of different oxidants due to E.coli.

\section{Conclusion}

In conclusion, many of these antioxidant pathways may be targeted for participation in oxidative stress. The results of the present study indicated that, the mRNA levels of antioxidant genes can be differed depending on the type of bacteria, and decreased expression of antioxidant genes could increase the susceptibility to mastitis.

\section{Conflict of interest statements}

The authors have no conflict with revealing information.

\section{Acknowledgements}

The author's thanks of University of Tabriz for providing the financial and logistics support for conducting this research work.

\section{References}

ABUELO, A., J. HERNÁNDEZ, J.L. BENEDITO, C. CASTILLO (2015): The importance of the oxidative status of dairy cattle in the periparturient period: revisiting antioxidant supplementation. J. Anim. Physiol. AN. N. 99, 1003-1116.

DOI: $10.1111 /$ jpn. 12273

AITKEN, S., E. KARCHER, P. REZAMAND, J. GANDY, M. VANDEHAAR, A. CAPUCO, L. SORDILLO (2009): Evaluation of antioxidant and proinflammatory gene expression in bovine mammary tissue during the periparturient period. J. Dairy. Sci. 92, 589-598.

DOI: $10.3168 /$ jds.2008-1551
ALERI, J. W., B. C. HINE, M. F. PYMAN, P. D. MANSELL, W. J. WALES, B. MALLARD, M. A. STEVENSON, A. D. FISHER (2019): Associations between immune competence, stress responsiveness, and production in Holstein-Friesian and Holstein-Friesian $\times$ Jersey heifers reared in a pasture-based production system in Australia. J. Dairy. Sci. 102, 3282-3294.

DOI: $10.3168 /$ jds.2018-14578

ARENAS, F. A., W. A. DÍAZ, C. A. LEAL, J. M. PÉREZDONOSO, J. A. IMLAY, C. C. VÁSQUEZ (2010): The Escherichia coli btuE gene, encodes a glutathione peroxidase that is induced under oxidative stress conditions. Biochemical and biophysical research communications. 398, 690-694.

DOI: 10.1016/j.bbrc.2010.07.002.

BIRBEN, E., U. M. SAHINER, C. SACKESEN, S. ERZURUM, O. KALAYCI (2012): Oxidative stress and antioxidant defense. World. Allergy Organ. J. 5, 9-19.

DOI: 10.1097/WOX.0b013e3182439613

CLEMENTS, M. O., S. P. WATSON, S. J. FOSTER (1999): Characterization of the major superoxide dismutase of Staphylococcus aureus and its role in starvation survival, stress resistance, and pathogenicity. J. Bacteriol. 181, 3898-3903.

DOI: 10.1128/JB.181.13.3898-3903.1999

CUSCHIERI, J., R. V. MAIER (2007): Oxidative stress, lipid rafts, and macrophage reprogramming. Antioxid. Redox. Signal. 9, 1485-1498.

DOI: 10.1089 /ars.2007.1670

DAS, D., B. BISHAYI (2009): Staphylococcal catalase protects intracellularly survived bacteria by destroying $\mathrm{H}_{2} \mathrm{O}_{2}$ produced by the murine peritoneal macrophages. Microb. Pathog. 47, 57-67.

DOI: 10.1016/j.micpath.2009.04.012

DENIS, M., N. A. PARLANE, S. J. LACY-HULBERT, E. L. SUMMERS, B. M. BUDDLE, D. N. WEDLOCK (2006): Bactericidal activity of macrophages against Streptococcus uberis is different in mammary gland secretions of lactating and drying off cows. Vet. Immunol. Immunopathol. 114,111-120.

DOI: 10.1016/j.vetimm.2006.08.001

EL-DEEB, W. M. (2013): Clinicobiochemical investigations of gangrenous mastitis in does: Immunological responses and oxidative stress biomarkers. J. Zhejiang. Univ. Sci. B. $14,33-39$.

DOI: $10.1631 /$ jzus.B1200123

HOVINEN, M., J. SIIVONEN, S. TAPONEN, L. HÄNNINEN, M. PASTELL, A. M. AISLA, S. PYÖRÄLÄ (2008): Detection of clinical mastitis with the help of a thermal camera. J. Dairy. Sci. 91, 4592-4598.

DOI: $10.3168 /$ jds.2008-1218 
IBRAHIM, H., Y. EL-SEEDY, N. GOMAA (2016): Cytokine response and oxidative stress status in dairy cows with acute clinical mastitis. J. Dairy. Vet. Anim. Res. 3, 00064. DOI: $10.15406 /$ jdvar.2016.03.00064

KARAVOLOS, M. H., M. J. HORSBURGH, E. INGHAM, S. J. FOSTER (2003): Role and regulation of the superoxide dismutases of Staphylococcus aureus. Microbiology 149, 2749-2758.

DOI: $10.1099 / \mathrm{mic} .0 .26353-0$

LIMA, L. S., M. F. PALIN, G. T. SANTOS, C. BENCHAAR, H. V. PETIT (2015): Effects of supplementation of flax meal and flax oil on mammary gene expression and activity of antioxidant enzymes in mammary tissue, plasma and erythrocytes of dairy cows. Livest. Sci. 176,196-204.

DOI: 10.1016/j.livsci.2015.03.015

MARKEY, B., F. LEONARD, M. ARCHAMBAULT, A. CULLINANE, D. MAGUIRE (2013): Clinical Veterinary Microbiology E-Book. Elsevier Health Sciences.

PETZL, W., H. ZERBE, J. GÜNTHER, H. M. SEYFERT, J. HUSSEN H. J. SCHUBERTH (2018): Pathogen-specific responses in the bovine udder. Models and immune prophylactic concepts. Res. Vet. Sci. 116, 55-61.

DOI: 10.1016/j.rvsc.2017.12.012

POKORSKA, J., D. KUŁAJ, M. DUSZA, J. ŻYCHLIŃSKABUCZEK, J. MAKULSKA (2016): New rapid method of DNA isolation from milk somatic cells. Anim. Biotechnol. 27, 113-117.

DOI: $10.1080 / 10495398.2015 .1116446$

QUINN, P. J., B. K. MARKEY, F. C. LEONARD, P. HARTIGAN, S. FANNING, E. I. FITZPATRICK (2011): Veterinary microbiology and microbial disease. John Wiley \& Sons.

RAY, A., G. COT M, PUZO, M. GILLERON, J. NIGOU (2013): Bacterial cell wall macroamphiphiles: pathogen-/ microbe-associated molecular patterns detected by mamma lian innate immune system. Biochimie. 95, 33-42.

DOI: 10.1016/j.biochi.2012.06.007

RINALDI, M., P. MORONI, M. J. PAAPE, D. D. BANNERMAN (2007): Evaluation of assays for the measurement of bovine neutrophil reactive oxygen species. Vet. Immunol. Immuno. Pathol. 115,107-125.

DOI: 10.1016/j.vetimm.2006.09.009

RUEGG, P. L. (2017). A 100-Year Review: Mastitis detection, management, and prevention. J. Dairy. Sci. 100, 1038110397.

DOI: $10.3168 /$ jds.2017-13023
SCHNEIDER, W. P., S. K. HO, J. CHRISTINE, M. YAO, A. MARRA, A. E. HROMOCKYJ (2002): Virulence gene identification by differential fluorescence induction analysis of Staphylococcus aureus gene expression during infection-simulating culture. Infect. Immun. 70, 13261333.

DOI: 10.1128/IAI.70.3.1326-1333.2002

SHARMA, L., A.K. VERMA, A. RAHAL, A. KUMAR, R. NIGAM (2016): Relationship between serum biomarkers and oxidative stress in dairy cattle and buffaloes with clinical and sub-clinical mastitis. Biotech. 15, 96-100.

DOI: 10.3923/biotech.2016.96.100

SHARMA, N., N. K. SINGH, O. P. SINGH, V. PANDEY, P. K. VERMA (2011): Oxidative stress and antioxidant status during transition period in dairy cows. Asian-Australas. J. Anim. Sci. 24,479-84.

DOI: 10.5713/ajas.2011.10220

SORDILLO, L. M., S. L. AITKEN (2009): Impact of oxidative stress on the health and immune function of dairy cattle. Vet. Immunol. Immunopathol. 128, 104-109.

DOI: 10.1016/j.vetimm.2008.10.305

VALCHEVA-TRAYKOVA, M., G. BOCHEVA, S. RAZMIROV, D. KARASHANOVA, T. TRAYKOV. (2018): Antioxidant effect of green synthesized silver nanoparticles on moderate local heat burn injury. Bulg. Chem. Commun, 50, 225-230.

WANKHADE, P. R., A. MANIMARAN, A. KUMARESAN, S. JEYAKUMAR, K. P. RAMESHA, V. SEJIAN, D. RAJENDRAN, M. R. VARGHESE (2017): Metabolic and immunological changes in transition dairy cows. Vet. World. 10, 1367.

DOI: 10.14202/vetworld.2017.1367-1377

WANG, H., H. CHEN, J. BIAN (2000): Studies on the activity of superoxide dismutase (SOD) in cows milk. J .Yellow. Cattleence. 26, 20-22.

WONG, S. H., J. A. KNIGHT, S. M. HOPFER, O. ZAHARIA, JR. C. N. LEACH, JR. F. W. SUNDERMAN (1987): Lipoperoxides in plasma as measured by liquidchromatographic separation of malondialdehydethiobarbituric acid adduct. Clinical. Chemistry. 33, 214220.

ZARRIN, M, L. GROSSEN-RÖSTI, R. M. BRUCKMAIER, J. J. GROSS (2017). Elevation of blood $\beta$-hydroxybutyrate concentration affects glucose metabolism in dairy cows before and after parturition. J. Dairy. Sci. 100, 2323-2333. DOI: $10.3168 /$ jds.2016-11714. 


\section{ASADPOUR, R., P. ZANGIBAND, K. NOFOUZI, A. SABERIVAND: Diferencijalna ekspresija antioksidacijskih gena za vrijeme kliničkog mastitisa krava uzrokovanog bakterijama Staphylococcus aureus i Escherichia coli. Vet. arhiv 91, 451-458, 2021.}

\section{SAŽETAK}

Postoji zanimanje istraživača za provjeru pretpostavke o vezi između oksidacijskog stresa i patofizioloških procesa tijekom kliničkog mastitisa. Glavni je cilj ovog istraživanja bio ustanoviti profil antioksidacijske genske ekspresije u mliječnih krava s kliničkim mastitisom. Uzorci mlijeka 77 krava s kliničkim mastitisom uzeti su između 15. i 70. dana laktacije (DIM) i analizirani standardnim bakteriološkim testovima. Istraživana je mRNA ekspresija antioksidacijskih gena, kao što je katalaza (CAT), glutation-peroksidaza (GPx) i superoksid-dismutaza (SOD). Osim toga u uzorcima mlijeka zdravih krava i onih s kliničkim mastitisom mjerene su razine lipidne peroksidacije. Izolirane su bakterije Staphylococcus aureus (S. aureus, 10,48 \%), Streptococcus agalactiae (7,69 \%), Streptococcus dysagalactiae (6,29 \%) i Escherichia coli (E. coli, 29,37 \%). Dominantan patogen pronađen u mlijeku krava s kliničkim mastitisom u ranoj laktaciji bila je bakterija $E$. coli. Prosječna vrijednost malondialdehida (MDA) u uzorcima krava s kliničkim mastitisom bila je znakovito veća $(\mathrm{P}<0,05)$ nego u zdravih krava. Rezultati su pokazali da je ekspresija profila SOD-a u mlijeku krava s mastitisom, inducirana bakterijom $S$. aureus, bila znakovito veća $(\mathrm{P}<0,0001)$ u usporedbi s $E$. coli. Također, ekspresija mRNA razine GPx-a u mlijeku krava s mastitisom zbog bakterije E. coli bila je znakovito veća $(\mathrm{P}<0,0001)$ u usporedbi s bakterijom $S$. aureus. Genska ekspresija CAT-a imala je tendenciju povećanja u mlijeku krava s mastitisom uzrokovanim bakterijom $S$. aureus u usporedbi s mlijekom krava koje su imale $E$. coli. Rezultati pokazuju da se mRNA razine antioksidacijskih gena mogu razlikovati ovisno o vrsti bakterije i da smanjena ekspresija antioksidacijskih gena može povećati prijemljivost na mastitis.

Ključne riječi: genska ekspresija; Staphylococcus aureus; Escherichia coli; mastitis; mliječne krave 